\title{
Metaphors of Entrepreneurship among Polish Students: Preliminary Research Findings
}

\author{
Michał Chmielecki, Łukasz Sułkowski
}

\begin{abstract}
A B S T R A C T
Objective: In Poland entrepreneurship is often perceived as an extremely risky process and entrepreneurs are often portrayed in a negative light. The research goals of our exploratory study is to identify the entrepreneurship metaphors among Polish management students.
\end{abstract}

Research Design \& Methods: Authors decided to run both qualitative and quantitative research. In the first part we addressed 124 management students on three levels $\mathrm{BA}, \mathrm{MA}$ and MBA. The respondents were asked to give their metaphorical expressions on paper. The next step was to prepare a questionnaire based on 7 point Likert scale. This questionnaire was run among BA management student group composed of 82 students.

Findings: Our results suggest that there are several major entrepreneurial narratives evident among all three groups including creativity and innovation, competition, war, journey, risk, adventure and exploitation.

Implications \& Recommendations: The empirical findings serve as a starting point for further in-depth research on entrepreneurship metaphors. It is recommended that in order to gain a complete picture of the issues underlying the results, both qualitative and quantitative research on a bigger sample should be undertaken.

Contribution \& Value Added: The originality of this work lies in studying some aspects of entrepreneurship metaphors among non-entrepreneurs in Poland. With regards to the research limitation, it must be highlighted that it was a pilot study and the results cannot be generalized.

\begin{tabular}{|c|c|c|}
\hline Article type: & research paper & \\
\hline Keywords: & $\begin{array}{l}\text { metaphors of entrepreneurship; entrepreneurship; } \\
\text { research; entrepreneurship education; Poland }\end{array}$ & metaphors; \\
\hline JEL codes: & M12, L26 & \\
\hline Received: $8 \mathrm{~F}$ & Revised: 20 September 2016 & tember 2016 \\
\hline
\end{tabular}

\section{Suggested citation:}

Chmielecki, M., \& Sułkowski, Ł. (2016). Metaphors of Entrepreneurship among Polish Students: Preliminary Research Findings. Entrepreneurial Business and Economics Review, 4(4), 141-151, DOI: http://dx.doi.org/10.15678/EBER.2016.040409 


\section{INTRODUCTION}

Entrepreneurship, has always been at the heart of economy's dynamics. Entrepreneurship continues to gain momentum as a significant and relevant research field. Policy makers in the rush to stimulate entrepreneurship in various countries, CEOs and company owners are looking for entrepreneurial employees (Chmielecki, 2013). Focus on entrepreneurship has been spurred by enormous popularity of start-up firms in high technology industries, the expansion of venture capital financing, successes of regional clusters, notably Silicon Valley and possibilities of crowdfunding. Some management scholars and social scientists interested in entrepreneurship focused their attention on studying metaphors of entrepreneurship. Unfortunately not much on this subject have been written in Polish context. As culture influences entrepreneurship, different nations have their own concepts of entrepreneurs and entrepreneurship.

The objective of this article is to is to identify the existing entrepreneurship metaphors among Polish management students, and this is an exploratory study at the very initial stage.

The article is divided into three main parts. At first literature is discussed, and the special attention was paid to metaphors in economic discourse. The second part briefly presents the methodological assumptions and the survey design. Finally, the articles elaborates on the survey results conducted among Polish students.

\section{LITERATURE REVIEW}

\section{Defining Entrepreneurship}

Entrepreneurship has always been a dominant force in economy. It changes the way we work, the way we communicate, the way we live. It generates Innovation, improves the quality of goods and services. Since the early 1980s, entrepreneurship has emerged as a topic of growing interest among social scientists and numerous management scholars (Cooper, 2003). Literature on entrepreneurs and entrepreneurship has stemmed from three main sources (Deakins, 1999):

1. economic authors who stress the role of the entrepreneur in economic development;

2. social and business authors who stress the influence of the social and business environment on entrepreneurship;

3. psychologists who focus on the personality traits of entrepreneurs.

A bit more detailed typology of entrepreneurship was proposed by Wach (2015), who tried to combine both economics and business studies, which resulted in distinguishing four primary and three secondary functions of entrepreneurship (Figure 1).

What is more, entrepreneurship is one of the most studied topics in economics and business research (Table 1). Concepts of entrepreneurship have been changing overtime. 
Table 1. Definitions and variables that describe entrepreneurship

\begin{tabular}{|c|c|c|}
\hline Author & The concept of entrepreneurship & Variables describing entrepreneurship \\
\hline $\begin{array}{l}\text { Schumpeter } \\
(1934)\end{array}$ & $\begin{array}{l}\text { Recognising opportunities for implementation of } \\
\text { ventures that are profitable and risk-taking to imple- } \\
\text { ment them. }\end{array}$ & $\begin{array}{l}\text { 1. The tendency to operate in conditions of } \\
\text { uncertainty } \\
\text { 2. Exploration and exploitation of market oppor- } \\
\text { tunities }\end{array}$ \\
\hline $\begin{array}{l}\text { Churchill } \\
(1983)\end{array}$ & $\begin{array}{l}\text { The process of discovery and development of capabil- } \\
\text { ities to create new value through innovation, acquisi- } \\
\text { tion of necessary resources and managing the pro- } \\
\text { cess of value creation. }\end{array}$ & $\begin{array}{l}\text { 1. Technological and organizational innovation } \\
\text { 2. Exploration and exploitation of market oppor- } \\
\text { tunities }\end{array}$ \\
\hline $\begin{array}{l}\text { Timmons } \\
(1990)\end{array}$ & $\begin{array}{l}\text { The process of creating or identifying opportunities } \\
\text { and using them despite of their current resources } \\
\text { (...). It is an creative act of an entrepreneur who finds } \\
\text { in him and devotes enough energy to initiate and } \\
\text { build a company or organization, rather than just } \\
\text { observe, analyse and describe it. }\end{array}$ & $\begin{array}{l}\text { 1. The tendency to operate in conditions of } \\
\text { uncertainty } \\
\text { 2. Exploration and exploitation of market } \\
\text { opportunities } \\
\text { 3. Entrepreneurial personality of a manager }\end{array}$ \\
\hline $\begin{array}{l}\text { Hisrich } \\
\text { \& Peters } \\
(1992)\end{array}$ & $\begin{array}{l}\text { The process of creating something different, because } \\
\text { of its value in the framework of which necessary time } \\
\text { and effort is devoted to achieve this goal, assuming } \\
\text { the accompanying financial, psychological and social } \\
\text { risk, and expecting obtaining financial rewards and } \\
\text { personal satisfaction. }\end{array}$ & $\begin{array}{l}\text { 1. Technological and organizational innovation } \\
\text { 2. The tendency to operate in conditions of } \\
\text { uncertainty } \\
\text { 3. Exploration and exploitation of market } \\
\text { opportunities } \\
\text { 4. Entrepreneurial personality of a manager }\end{array}$ \\
\hline \begin{tabular}{|l} 
Frey \\
$(1993)$
\end{tabular} & $\begin{array}{l}\text { Starting a venture and (or) its growth, which occurs } \\
\text { through the use of innovation, by management } \\
\text { assuming the risk. }\end{array}$ & $\begin{array}{l}\text { 1. Technological and organizational innovation } \\
\text { 2. The tendency to operate in conditions of } \\
\text { uncertainty }\end{array}$ \\
\hline $\begin{array}{l}\text { Piasecki } \\
(1998)\end{array}$ & $\begin{array}{l}\text { Entrepreneurship is the process: } \\
\text { - which includes the action taken for the analysis of } \\
\text { opportunities of start and development (or just } \\
\text { development) of the venture, its financing and the } \\
\text { possibility of meeting the effects of such action; } \\
\text { - which can take many different forms and shapes, } \\
\text { including initiation of a venture, creativity and inno- } \\
\text { vation in developing new products or services, } \\
\text { managing an existing venture in such a way that it } \\
\text { develops quickly and continuously, seeking financial } \\
\text { and material supply sources for potentially growing } \\
\text { number of ventures, accepting risk in the develop- } \\
\text { ment of new or expansion of existing ventures } \\
\text { (these elements are the part of the entrepreneurial } \\
\text { process, although not all of them must participate } \\
\text { in each activity). }\end{array}$ & $\begin{array}{l}\text { 1. Technological and organizational innovation } \\
\text { 2. The tendency to operate in conditions of } \\
\text { uncertainty } \\
\text { 3. Market and intraorganizational flexibility } \\
\text { 4. Exploration and exploitation of market } \\
\text { opportunities } \\
\text { 5. Entrepreneurial personality of a manager }\end{array}$ \\
\hline $\begin{array}{l}\text { Kraśnicka } \\
(2001)\end{array}$ & $\begin{array}{l}\text { Entrepreneurship is an activity that stands out by: } \\
\text { activity and dynamism, innovation, looking for } \\
\text { changes and reacting to them, perceiving opportuni- } \\
\text { ties and their use, regardless of the resources (at the } \\
\text { moment), willingness to take risks, which main } \\
\text { motive is to multiply the capital. }\end{array}$ & $\begin{array}{l}\text { 1. The tendency to operate in conditions of } \\
\text { uncertainty } \\
\text { 2. Technological and organizational innovation } \\
\text { 3. Market and intraorganizational flexibility } \\
\text { 4. Exploration and exploitation of market } \\
\text { opportunities }\end{array}$ \\
\hline $\begin{array}{l}\text { Sudoł } \\
\text { (2008) }\end{array}$ & $\begin{array}{l}\text { Feature (way of behaving) of entrepreneurs and } \\
\text { companies, that means the willingness and ability to } \\
\text { undertake and solve creative and innovative new } \\
\text { problems, while taking into consideration its risks, } \\
\text { the ability to use the available opportunities and } \\
\text { flexibility to adapt to changing conditions }\end{array}$ & $\begin{array}{l}\text { 1. Technological and organizational innovation } \\
\text { 2. Market and intraorganizational flexibility } \\
\text { 3. Exploration and exploitation of market } \\
\text { opportunities } \\
\text { 4. Entrepreneurial personality of a manager }\end{array}$ \\
\hline
\end{tabular}

Source: own compilation based on the cited references. 
As Sułkowski (2012) noticed "in many of the listed definitions, the following variables describe entrepreneurship as:

1. a process of innovative and creative markets activities or organizational changes (technological and organizational innovation);

2. taking risks in business or tolerance of uncertainty aiming at the development of the venture (the tendency to act under uncertainty);

3. flexibility in relation to strategy and market activities and the willingness to change and intraorganizational flexibility (market and organizational flexibility);

4. exploration and exploitation of opportunities inherent in the environment of the organization and the unique competitive advantages of having support in the organizational resources (exploration opportunities);

5. a set of entrepreneurial characteristics such as innovation, creativity, willingness to take risks, and orientation to change (the entrepreneurial personality).

Summarizing the above definitions we can agree that entrepreneurship is the transformation of an innovation into an enterprise generating value.

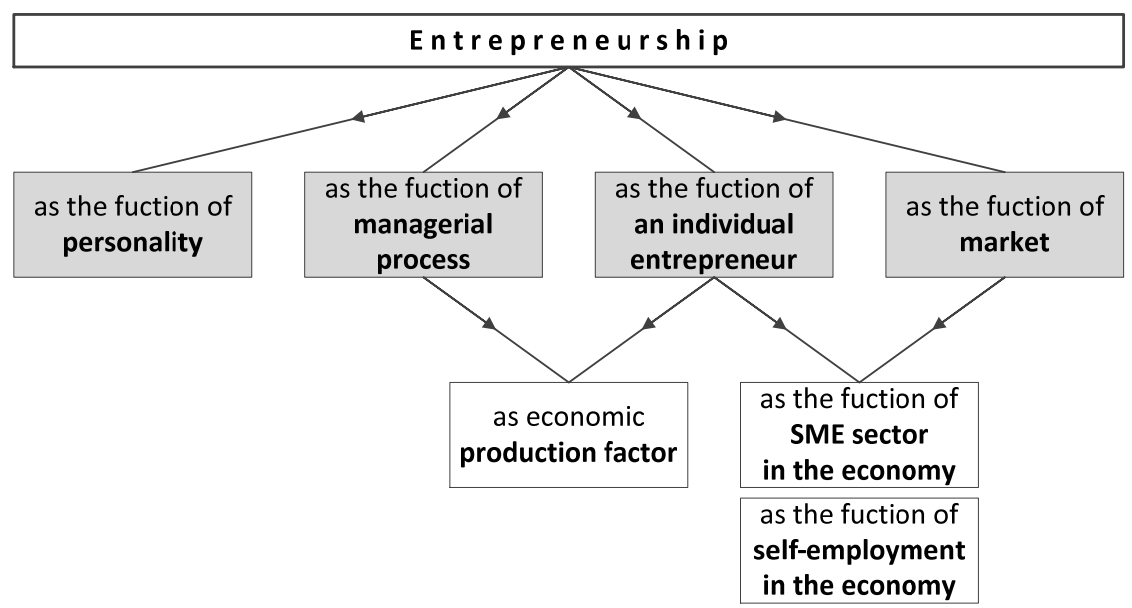

Figure 1. Basic functions of entrepreneurship in economics and business studies Source: Wach (2015, p. 14).

\section{Metaphors in Economic Discourse}

Metaphors have been an important object of interest along centuries. It has been the focus of various studies, research, analysis and theory, starting from Aristotle and going on till now. Contrary to standard thought, metaphors pervade our thinking and conceptualization rather than serving a poetic and rhetorical device. In the field of communication and to be more precise, linguistics, it has been accepted that our thoughts and cognitive processes are highly metaphorical i.e. metaphors constitute and construct human thoughts (Lakoff \& Johnson, 1980; 2003). Deignan (2005, p. 18) believes that language is hardly metaphor-free suggesting that people think in metaphors and become familiar with new domains due to metaphorical thinking (Lakoff \& Johnson, 1980; Gentner 
\& Jeziorski, 1993), since analogical reasoning leads to new insights in either a new or familiar concepts (Schön, 1993; Walsh, 1995).

Metaphor is common in economic discourse (McCloskey, 1995). Many terms in economics such as inflation, depression or expansion, are metaphorical in their very own nature. However, it was 1982, when W. Henderson opened the discussion of metaphor in economics, emphasizing the scarcity of analyses of metaphor in economics, in spite of the wide and deliberate use of metaphor in economic texts. Finally, the 1980s brought the emergence of metaphors from the closet. Lakoff and Johnson (1980) were the pioneers in this field. They demonstrated the pervasiveness of metaphorical reasoning. According to them, metaphors were necessary for humankind's understanding. In the twenty-five years since the Peters and Waterman's triumph, the use of metaphors gained strength. Every imaginable academic discipline started using metaphors (Knowles \& Moon, 2006). This was more so in the business and management fields.

This "metaphoromania" of the last three decades resulted in a lot of research, which deals with the following processes: identification, comparison and juxtaposition, and the two dimensions of metaphor, i.e. the instrument of thinking used to shape a certain discipline and, paradoxically, the outcome of the light shed upon the metaphorical process itself. Thus, metaphor is considered both a tool of forming various sciences and a result of the way in which these sciences developed (Vasiloaia, Gaisoa, \& Vergara, 2011).

\section{Metaphors of Entrepreneurship}

Charteris-Black (2004) emphasizes that metaphors involve a transfer of meanings. The use of a metaphor allows people to map a schema, well-known to them onto a new domain and assess the fit of relationships between variables from one to another (Wickman, Daniels, White \& Fesmire, 1999). This facilitates understanding of complex and abstract ideas (Palmer \& Dunford, 1996), such as entrepreneurship. Metaphors are known to capture experience and emotions better than literal discourse (Palmer \& Dunford, 1996).

Research concerning metaphors is well established within the entrepreneurship field. Scholars have studied the metaphors for entrepreneurship used by entrepreneurs (Hyrsky, 1999; Dodd, 2002) and non-entrepreneurs (Koiranen, 1995). Many have studied the metaphors media use to portray entrepreneurs (Nicholson \& Anderson, 2005). The use of metaphors for sense-making and sense-giving among entrepreneurs was also a subject of research (Hill \& Levenhagen, 1995). However, the use of metaphors for entrepreneurship in Poland is still heavily under-researched.

\section{MATERIAL AND METHODS}

The research goals of our exploratory study is to identify entrepreneurship metaphors among Polish management students. This research will focus on metaphors of entrepreneurship used by non-entrepreneurs. The research procedure employed was qualitative in nature. We reached students of the University of Social Sciences in Łódź in late 2015. We reached the students we had classes with, so it was not a random sample. Thus, the presented results are not representative, but they can illustrate the basic image in the undertaken theme among students from Poland. 
We had two stages of the investigation. We addressed 124 management students on three levels, namely bachelor (BA), master (MA) and post-graduate (MBA) and they constituted the first research group. The second research group consisted of 82 students at the bachelor level only. The first group was used for experimental phase of research and the second group was used for the survey questionnaire.

\section{RESULTS AND DISCUSSION}

The first research group consisted of 124 students. The respondents were asked to give their metaphorical expressions on paper. As far sex is concerned the group was diversified as $54 \%$ of the respondents were female and $46 \%$ were male. The average age of respondents was 29 years and the average number of years of employment among respondents was 6.8 . 33\% of the respondents said that either their parents or close relatives were or had been business owners. None of the respondents had any experience either in setting up or in running their own business.

Student respondents were asked to create the metaphors of their own accord. They were encouraged to follow their first instincts in forming lexical associations depicting the essential characteristics of a entrepreneurship. Metaphors were grouped into 8 different clusters based on their semantic properties (Table 2). Our results suggest that there are several major entrepreneurial narratives evident among all three groups including creativity and innovation, competition, war, journey, risk, adventure and exploitation.

The next step was to prepare a questionnaire based on 7-point Likert scale. This questionnaire was run among BA management student group composed of 82 students only (the second research group).

As for sex the sample was diversified as 50 of the respondents were female and 32 were male. The average age of respondents was 27 years and the average number of years of employment among respondents was 5.6. 12 respondents said that either their parents or close relatives were or had been business owners. None of the respondents had any experience either in setting up or in running their own business.

Based on 7-point Likert scale, in order to generalize results we calculated the basics descriptive statistics - mean and standard deviation. Although some statisticians negate such solutions, numerous studies published even in the top-ranking journals of business studies accept such an approach (Ozaralli \& Rivenburgh, 2016; Wach \& Wojciechowski, 2016). The results are depicted in Table 3.

Hayton, George and Zahra (2002) stress that cultural values serve as a filter for the degree to which a society considers certain entrepreneurial behaviours as desirable. Moreover, numerous authors have emphasized the importance of understanding the impact of cultural norms on entrepreneurship. Several researchers acknowledge the importance of the cultural context for career decisions as entrepreneurs (Flores, Robitschek, Celebi, Andersen \& Hoang, 2010; Leong, 2010). 
Table 2. The content analysis of the metaphors of entrepreneurship among surveyed students

\begin{tabular}{|c|c|c|}
\hline No. & $\begin{array}{l}\text { Metaphor } \\
\text { Category }\end{array}$ & Examples \\
\hline 1. & $\begin{array}{l}\text { Creativity } \\
\text { or } \\
\text { innovation }\end{array}$ & $\begin{array}{l}\text { The respondents provided for example the following expressions to empha- } \\
\text { size the ideas of creativity and innovations: } \\
\text { "Entrepreneurship is building something out of elements which are initially } \\
\text { not connected" } \\
\text { "Entrepreneurship is like constant problem solving exercise" } \\
\text { "Entrepreneurship is creating solutions" } \\
\text { "Entrepreneurship is building a fast path to the future you want." }\end{array}$ \\
\hline 2. & Competition & $\begin{array}{l}\text { The metaphors indicating competition: } \\
\text { "Entrepreneurship is a race for money" } \\
\text { "Entrepreneurship is a track race" } \\
\text { "Entrepreneurship is like wrestling" } \\
\text { "Entrepreneurship is a marathon race" } \\
\text { "Entrepreneurship is a competition" }\end{array}$ \\
\hline 3. & Journey & $\begin{array}{l}\text { The metaphors indicating journey: } \\
\text { "Entrepreneurship is like conquering a steep hill, one after another" } \\
\text { "Entrepreneurship is a never ending journey full of new people, places and } \\
\text { situations" }\end{array}$ \\
\hline 4. & War & $\begin{array}{l}\text { The metaphors indicating war: } \\
\text { "Entrepreneurship is a war" } \\
\text { "Entrepreneurship is a war game against taxes and taxcouncil" } \\
\text { "Entrepreneurship is a constant battle" } \\
\text { "Entrepreneurship is a survival game" } \\
\text { "Entrepreneurship is like being on a battlefield, every day, all day long" }\end{array}$ \\
\hline 5. & Adventure & $\begin{array}{l}\text { The metaphors indicating adventurers: } \\
\text { "Entrepreneurship is blazing new trails" } \\
\text { "Entrepreneurship is swimming across a stormy seas" }\end{array}$ \\
\hline 6. & Exploitation & $\begin{array}{l}\text { Metaphors indicating exploitation of others: } \\
\text { "Entrepreneurship is exploiting other people" } \\
\text { "Entrepreneurship is taking advantage of employees" } \\
\text { "Entrepreneurship is squeezing as much as you can form others" }\end{array}$ \\
\hline 7. & Risk & $\begin{array}{l}\text { Metaphors indicating risk: } \\
\text { "Entrepreneurship is like walking on a tightrope" } \\
\text { "Entrepreneurship is like skating on thin ice" } \\
\text { "Entrepreneurship is like a Russian roulette" }\end{array}$ \\
\hline 8. & Miscellaneous & $\begin{array}{l}\text { Some miscellaneous metaphors were used, such as: } \\
\text { "Entrepreneurship is the key to success in life" } \\
\text { "Entrepreneurship is dreaming big, and getting big" } \\
\text { "Entrepreneurship is like workaholism but in a positive way" } \\
\text { "Entrepreneurship as a style of living" } \\
\text { "Entrepreneurship is like harvesting - you reap what you sow" } \\
\text { "Entrepreneurship is hunting for clients" }\end{array}$ \\
\hline
\end{tabular}

Source: own study based on open questions ( $n=124)$. 
Table 3. Entrepreneurship metaphors among surveyed students

\begin{tabular}{|l|c|c|}
\hline \multicolumn{1}{|c|}{ Metaphor } & Mean & Std. Dev. \\
\hline Creativity/innovation & 3.353 & 1.399 \\
\hline Competition & 5.061 & 1.390 \\
\hline Journey & 2.902 & 1.384 \\
\hline War & 5.695 & 1.038 \\
\hline Adventure & 3.975 & 1.333 \\
\hline Exploitation & 2.353 & 1.115 \\
\hline Risk & 5.195 & 1.261 \\
\hline
\end{tabular}

Source: own study based on the survey $(n=82)$.

Metaphors of entrepreneurship are under the influence of certain well-established patterns and stereotypes in Polish culture. There were numerous negative metaphors indicating exploitation of others. "Exploiting other people" or "taking advantage of employees" were just a few examples of metaphors with negative, cynical or downgrading undertones.

However, findings illustrate the change in the perception of entrepreneurship among non-entrepreneurs in Poland. Although as we have expected in our introductory research most of the metaphors would reflect competition ("a race for money", "a marathon race"), war ("war against taxes and tax council" and risk ("skating on thin ice" or "Russian roulette"), we may observe many optimistic metaphors. According to this perception entrepreneurship is oftentimes viewed a "key to success in life" or "building a fast path to the future you want". It's very often associated with good and innovative ideas, creativity, freshness and breaking stereotypes.

Some metaphors illustrate the approach to entrepreneurship as part of a lifestyle providing self-direction and self-control. Here comes the tendency to escape from competing and fighting, and move towards balancing and harmonizing own life in relation to business.

\section{CONCLUSIONS}

The metaphorical statements revealed the paradoxical nature of respondents' perceptions of entrepreneurship. A majority of the metaphors contained quite negative images. Especially in the least educated group sample they seemed to conjure up most negative images of entrepreneurship as some kind of modern day "slave owners" or exploiters.

We believe that metaphors play an important role in popularizing business and business related concepts and enhance our understanding in the nature of the different metaphors used in economics discourse. Because metaphors shape the way we think, our choices of metaphors are important. Gartner (1993) has suggested that "the words we use to talk about entrepreneurship influence our ability to think about this phenomenon". Subsequently these thoughts are able change the discourse about entrepreneurship and direct actions toward entrepreneurial activities which ultimately affect culture and support the activation of entrepreneurial attitudes in social circles.

The main research limitation is the non-representativeness of the sample as well as small sample size ( $n=124$ at the first stage and $n=84$ at the second stage). The results 
presented in the article are very preliminary and further investigations in this field are needed. It seems necessary to conduct a survey among a larger sample of students and to include more explaining variables.

\section{REFERENCES}

Charteris-Black, J. (2004). Corpus Approaches to Critical Metaphor Analysis. New York: Palgrave Macmillan.

Chmielecki, M. (2013). Development of corporate entrepreneurship in the context of human resource management and organizational culture in Polish organizations - research results. Przedsiębiorczość i Zarzq̨dzanie, 14(9), 101-116.

Churchill, N., \& Levis, V. (1983).The Five Stages of Small Business Growth. Harvard Business Review, May-June.

Cooper, A. (2003). Entrepreneurship: The Past, the Present, the Future. In Z.J. Acs \& D. Audretsch (Eds.), Handbook of Entrepreneurship Research (pp. 21-34). Boston: Kluwer.

Deakins, D. (1999). Entrepreneurship and Small Firms. London: McGraw-Hill.

Deignan, A. (2005). Metaphor and corpus linguistics. Amsterdam - Philadelphia: John Benjamins.

Dodd, S.D. (2002). Metaphors and meaning: A grounded cultural model of US entrepreneurship. Journal of Business Venturing, 17(5), 519-535.

Frey, R.F. (1993). Enterprenaurship. A Planing Approach. Eagan: West Publishing Company.

Gartener, W.C. (1993). Image formation process. Journal of Travel and Tourism Marketing, 2(2-3), 191-216.

Gentner, D., \& Jeziorski, M. (1993). The Shift From Metaphor To Analogy In Western Science. In A. Ortony (Ed.), Metaphor and Thought (pp. 447-480). Cambridge, England: Cambridge University Press.

Flores, L.Y., Robitschek, C., Celebi, E., Andersen, C., \& Hoang, U. (2010). Social cognitive influences on Mexican Americans' career choices across Holland's themes. Journal of Vocational Behavior, 76, 198-210.

Hayton, J.C., George, G., \& Zahra, S.A. (2002). National Culture and Entrepreneurship: A Review of Behavioral Research. Entrepreneurship Theory and Practice, 26(4), 33-52.

Henderson, W. (1982). Metaphor in Economics. Economics, 18(4), 147-157.

Hill, R.C., \& Levenhagen, M. (1995). Metaphors and mental models: Sensemaking and sensegiving in innovative and entrepreneurial activities. Journal of Management, (21)6, 1057-1074.

Hisrich, R.D., \& Peters, M.P. (1992). Entrepreneurship. Starting, Developing and Managing a New Enterprise. 2nd ed. Boston: IRWING.

Hyrsky, K. (1999). Entrepreneurial metaphors and concepts: An exploratory study. International Small Business Journal, 18(1), 13-34.

Knowles, M., \& Moon, R. (2006). Introducing Metaphor. Abingdon: Routledge.

Koiranen, M. (1995). North-European metaphors and of 'entrepreneurship' and 'an entrepreneur'. Frontiers of Entrepreneurship Research, 1995 Edition, pp. 203-216.

Kraśnicka, T. (2001). Przedsiębiorczość jako przedmiot badań ekonomistów. Ekonomia, 4, 187-200.

Lakoff, G., \& Johnson, M. (1980). Metaphors we live by. Chicago: University of Chicago Press.

Leong, F.T.L. (2010). A Cultural Formulation Approach to Career Assessment and Career Counseling: Guest Editor's Introduction. Journal of Career Development, 37, 375-390. 
McCloskey, D. (1995). Metaphors Economists Live By. Social Research, 62(2), 215-237.

Nicholson, L., \& Anderson, A. (2005). News and nuances of the entrepreneurial myth and metaphor: Linguistic games in entrepreneurial sense-making and sense-giving. Entrepreneurship Theory and Practice, 29, 153-172.

Ozaralli, N., \& Rivenburgh , N.K. (2016). Entrepreneurial intention: antecedents to entrepreneurial behavior in the U.S.A. and Turkey. Journal of Global Entrepreneurship Research, 6(3). doi: 10.1186/s40497-016-0047-x

Palmer, I., \& Dunford, R. (1996). Conflicting uses of metaphors: Reconceptualizing their use in the field of organizational change. Academy of Management Review, 21(3), 691-717.

Timmons, J. (1990). New Venture Creation. Boston: IRVIN.

Piasecki, B. (1998). Przedsiębiorczość i mała firma. Łódź: Wydawnictwo Uniwersytetu Łódzkiego.

Schumpeter, J.A. (1934|2008). The Theory of Economic Development: An Inquiry into Profits, Capital, Credit, Interest and the Business Cycle. New Brunswick - London: Transaction Publishers.

Schön, D.A. (1979). Generative Metaphor: A Perspective On Problem Setting in Social Policy. In A. Ortony (Ed.), Metaphor and Thought (pp. 137-163). Cambridge, England: Cambridge University Press.

Sudoł, S. (2008). Przedsiębiorczość - jej pojmowanie, typy i czynniki ją kształtujące. Problemy Zarzq̨dzania, 6(2), 9-26.

Sułkowski, Ł. (2012). Barriers to entrepreneurship in the management of hospitals in Poland. In C. Martin \& T. Rkibi (Eds.), L'entrepreneur face aux politiques publiques europeennes (pp. 382388). Lisboa: PGV/ISLA.

Vasiloaia, M., Gaisoa, M., \& Vergara, N. (2011). Metaphors business linguistic culture lives by. Economy Transdisciplinarity Cognition, 14(1), 231-240.

Wach, K. (2015). Przedsiębiorczość jako czynnik rozwoju społeczno-gospodarczego: przegląd literatury. Przedsiębiorczość - Edukacja, 11, 24-36.

Wach, K., \& Wojciechowski, L. (2016). Entrepreneurial Intentions of Students in Poland in the View of Ajzen's Theory of Planned Behaviour. Entrepreneurial Business and Economics Review, 4(1), 83-94. doi: http://dx.doi.org/10.15678/EBER.2016.040106

Walsh, J.P. (1995). Managerial and organizational cognition: Notes from a trip down memory lane. Organization Science, 6, 280-321.

Wickman, S., Daniels, M., White, L., \& Fesmire, S. (1999). A primer in conceptual metaphor for counselors. Journal of Counseling \& Development, 77(4), 389-394. 


\section{Authors}

The contribution share of authors is equal and amounted to $50 \%$ each of them.

\section{Michał Chmielecki}

Assistant Professor at Clark University (MA, USA) and the University of Social Sciences (Poland), where he teaches Negotiation and Conflict Resolution, Cross-Cultural Communication and Business Communication, among others, to MBA and MSPC students. He is also the head of the International Cooperation Department at the University of Social Sciences. He serve as the associate editor of the Journal of Intercultural Management, editor of the Entrepreneurship and Management Journal, and the secretary of the Intercultural Management Congress. He has ten years of experience in conducting corporate trainings and consulting. He specializes in cross-cultural negotiations.

Correspondence to: Dr. Michal Chmielecki; University of Social Sciences, Department of Management; ul. Sienkiewicza 9, 90-113 Lodz, Poland; e-mail: mchmielecki@spoleczna.pl

\section{Łukasz Sułkowski}

Member of the Presidium of the Polish Accreditation Committee and Director of Academic Development Centre of the Academy of Social Sciences form 2004 to 2011 he was a Vice-Rector for Quality of Education Academy of Management in Lodz. He is also Head of the Department of Public Administration at the Jagiellonian University and a Professor in the Department of Public Management at the Jagiellonian University. He serves as a Chief Editor of the Quarterly "Journal of Intercultural Management". His main research interests are: organizational culture, intercultural management, social determinants of management, the methodology of management, the development of human resources, the methodology of educating and training personnel. His academic output includes over 300 publications in the field of management.

Correspondence to: Prof. dr hab. Łukasz Sułkowski; University of Social Sciences, Department of Management; ul. Sienkiewicza 9, 90-113 Lodz, Poland; e-mail: Isulkowski@spoleczna.pl

\section{Copyright and License}

This article is published under the terms of the Creative Commons Attribution - NonCommercial - NoDerivs (CC BY-NC-ND 3.0) License http://creativecommons.org/licenses/by-nc-nd/3.0/ 
